\title{
Performance Analysis of a Savonius Wind Turbine in the Solar Integrated Rotor House
}

\author{
ABDUL LATIF MANGANHAR*, ALTAF HUSSAIN RAJPAR**, AND SALEEM RAZA SAMO** \\ RECEIVED ON 30.06.2015 ACCEPTED ON 16.08.2016 \\ ABSTRACT
}

\begin{abstract}
Rooftop, building integrated and building augmented micro wind systems have the potential for small scale power generation in the built environment. Nevertheless, the expansion of micro wind technology is very slow and its market is strongly affected by the low efficiency of conventional wind generators. WAG-RH (Wind Accelerating and Guiding Rotor House) which is a new technique introduced to enhance the efficiency of vertical axis rotor. The present study utilizes other green energy element by integrating the WAG-RH with a solar heating system. In this effort roof of the WAG-RH has been utilized to heat air through micro solar chimney for creating buoyancy effect in the air flow channel at rotor zone in the WAG-RH. The integration is capable of improving the performance of rotor setup in the WAG-RH as well as providing hot air with sufficient air mass flow rate for space heating. The WAG-RH had brought about $138 \%$ increase in the performance coefficient(Cp) of conventional three bladed Savonius rotor, whereas solar integrated WAG-RH has contributed $162 \%$ increase in the $\mathrm{Cp}$ of the same rotor.
\end{abstract}

Key Words: Rooftop, Micro Wind Technology, Rotor Efficiency, Air Heater, Buoyancy Effect, Savonius Rotor.

\section{INTRODUCTION}

$\Gamma$

he rapid increases in global population as well continuous development in living standards have been introducing a great pressure on the power industry. Fossil natural resources are therefore becoming exhausted at an alarming rate to produce power and fulfill requirements in the developing economy. By the fast use of fossil fuels considerable climate change has been occurred causing several environmental impacts such as, global warming, melting of glaciers, air and water degradation, loss of biodiversity, and acidification of oceans [1-3]. The urgent solution is to use clean and renewable energy sources as well as develop efficient technologies. Utilization of Wind and solar energies are the best alternative of fossil fuels for power generation. Both are freely available, reliable and clean energy sources.

The ascending trend of power generation from renewable energy sources shows good share of wind energy and plays a major role in replacement of fossil fuels [4,5]. The estimates are that, wind energy is expected to provide about $9 \%$ of global electricity by 2030 and about $12 \%$ by $2050[6,7]$.

*Department of Mechanical Engineering, Quaid-e-Awam University of Engineering, Science \& Technology, Nawabshah.

Mehran University Research Journal of Engineering \& Technology, Volume 36, No. 3, July, 2017 [p-ISSN: 0254-7821, e-ISSN: 2413-7219] 
Though, building-integrated micro-wind turbines are the potentially low-cost wind power generating systems but the reasons behind their limited installation in urban areas are the low mean wind speeds, and high levels of turbulence [8,9].

The systems designs which incorporate such wind conditions and have ability to increase flow velocity in the rotor zone [10-14] were being suggested for the built environment. In this connection the literature prefers the use of wind turbine enclosures with wind accelerating characteristics [15-18].

It is also notable that the socio-economic development of any nation in the world depends on the provision of reliable electricity supply systems. However, a significant drawback of the two major renewable energy sources, such as, solar and wind is that their output power depends largely on the unpredictable weather or climatic changes. The renewable energy systems working in hybrid techniques have been preferred to cover such drawbacks. One source of energy can cover the weakness of the other, hence, improves the generation, economy and reliability of system. One of the advantages of a wind and solar hybrid system is that its reliability is enhanced compared with their simple working systems [19-21].

Solar air heating is a renewable energy heating technology employed to heat or condition air for buildings or process heat applications. A solar air collector integrated with a central updraft tower which has been employed, since long, for generating solar induced air flow to ventilate buildings and the power of this air flow to drive turbines for generating electricity[22-24]. In the ventilation process air contained in the solar collector, is heated by solar heat flux so that its density is reduced. The central updraft tower being opened at upper end allows the less density lighter air to be pulled by buoyancy to flow upward through the tower or a chimney-liked structure. A solar collector intake, opens in the structure to be ventilated, sucks impure air, which, is manipulated to induce the surrounding air to ventilate the building. Solar chimney system which, can make full use of solar energy to produce upward momentum to a mass of air thereby converting thermal energy into kinetic energy.

Here, the literature concludes with recommendations that clean and renewable energy sources must be preferred. Building-integrated micro-wind turbines are better choice but their limitations should be addressed by using efficient technologies. Combination of two green energy elements is mostly suggested for power generation enhancement and achieves reliability.

Present study involved in exploration of efficient technology and supported from two green energy resources such as wind and solar. The study, in general, introduces a house for Vertical Axis Wind Turbine where the rotor receives accelerated wind stream contributed by combined action of house design and the buoyancy effect created through solar air heater working as an integral part of the house. This paper covers only the contribution of a micro solar air heating system that has been proposed to install as an integral part of the rotor house. Air heater intakes atmospheric air from upper opening of rotor in the $\mathrm{RH}$ and releases warm air through central updraft tower. The objective is to utilize the roof of RH for getting hot air for space heating, as well as, generate additional air flow in the rotor zone that may support the rotor and enhance its performance in the RH.

\section{MATERIALS AND METHOD}

The WAG-RH is a novel technique proposed by the author to improve performance of vertical axis wind turbine. The WAG-RH improved the performance coefficient of a three bladed Savonius rotor up to $138 \%$. The rotor house is an omni-directional structure which

Mehran University Research Journal of Engineering \& Technology, Volume 36, No. 3, July, 2017 [p-ISSN: 0254-7821, e-ISSN: 2413-7219] 
encloses the rotor and provides better location where rotor can receive accelerated wind streams entering from any direction.

Present study is an effort to investigate the benefits of solar air heater integration with the WAG-RH. In this connection a solar air heater model has been framed on the top surface(roof) of the WAG-RH model.

The geometry and working of WAG-RH model is such that the four equidistant vertical walls tilted at 45 degree clockwise with each reference axis surround the rotor as shown in Fig. 1. The tilted wall diverts or deflects the wind stream, entering in the rotor house, towards the beneficial location of the rotor zone. Further, the combined actions of two adjacent walls, in this arrangement, gives venturi effect and accelerate incoming wind at their converged end which exits in the rotor zone.

WAG-RH has a flat roof with circular opening of diameter equal to the diameter of rotor zone at its centre. The flat roof has been used in this study, to install a solar air heater. A chimney type shape solar air heater simulator

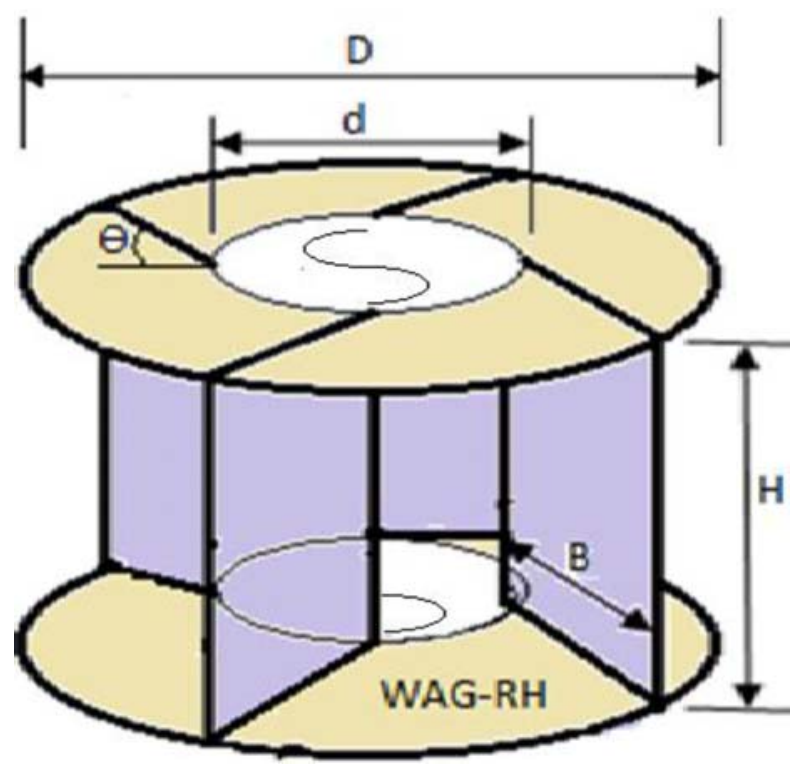

FIG. 1. WIND ACCELERATING AND GUIDING ROTOR HOUSE was developed and used to investigate overall performance. The air heater consists of a horizontal hallow circular flat area, a transparent plastic sheet for glazing, a small vertical tower and electric heater. The size of air heater with tower is taken same as the size of WAG-RH, i.e. diameter of heater area $0.8 \mathrm{~m}$ and over all height of air heater including tower $0.3 \mathrm{~m}$.

The air heater heats up the air available in the heater space zone, changes density of air and generates flow in the air creating buoyancy effect. The buoyant flow intakes air from the upper circular opening located at the centre of WAG-RH roof and exits air from the tower located at the centre of air heater as indicated in Fig. 2. The air flow channel(HV-Channel) starts horizontally from the inlet of WAG-RH, diverts vertically via upper opening of rotor zone(heater inlet) and ends at tower exit.

\subsection{Methodology}

Changing temperature at the hot space with the help of electric heater affects the velocity of air in the HV-channel. Temperature and air velocity at various points of importance were measured using thermocouples and hot wire anemometer respectively.

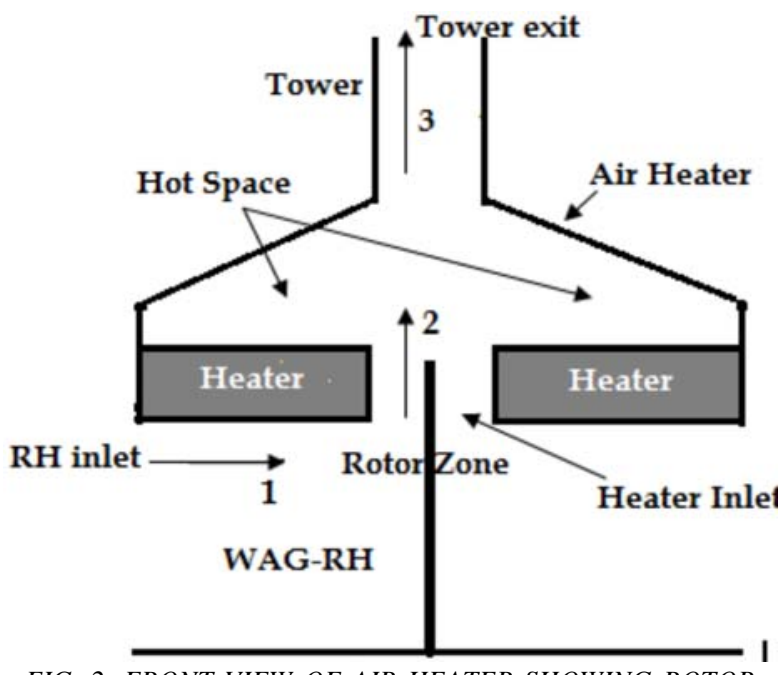

FIG. 2. FRONT VIEW OF AIR HEATER SHOWING ROTOR ZONE AND AIR FLOW CHANNEL (HV-CHANNEL)

Mehran University Research Journal of Engineering \& Technology, Volume 36, No. 3, July, 2017 [p-ISSN: 0254-7821, e-ISSN: 2413-7219] 
Further, the effect of air flow in the HV-channel on the performance of rotor inside the WAG-RH was investigated without and with additional wind flow from wind tunnel.

The VHCBC (Vertical-Horizontal Co-Axial Blades Combination) technique [25] was used to utilize both the flow (horizontal by wind tunnel and vertical by buoyancy) properly. In this technique four bladed horizontal axis setup was fixed vertically with the upper end of shaft of vertical axis rotor to trap vertical air flow at the air heater inlet.

\section{RESULTS AND DISCUSSION}

The HST (Hot Space Temperature) was used to create density gradient and generate air flow in the HVchannel.The thermostat control system consisting of thermocouples, a digital meter and temperature setting switches were used to control the HST.

At the initial stage, buoyant flow in the HV-channel was developed only by increasing temperature in the hot space. At each increase in the hot space temperature air flow velocity and temperature at three locations in the channel were recorded. At the second stage same tests were repeated considering the effect of external wind flow passing through the rotor $\mathrm{RH}$ on the air velocity in the HV-channel. At the third stage, performance of the rotor in WAG-RH was investigated for buoyant flow, without and with considering the effect of external wind flow. Thirty readings of each parameter at each variation of hot space temperature were recorded to take average value of the measurement and avoid error occurrence in the data.

\subsection{Air Flow in the $\mathrm{HV}$-Channel}

Air flow velocity, mass flow rate and air flow temperature at different locations in the HV-channel have been investigated for different hot space temperatures, with and without any support from external wind flow.

\subsubsection{Buoyancy Operated Air Flow}

The flow of air in the channel was developed due to buoyancy caused by density difference of the hotter air molecules at the upper portion and colder air molecules at the lower portion of the flow channel. The developed air flow velocity and the air flow temperature in the flow channel was measured at three locations such as, $\mathrm{RH}$ (Rotor House) inlet, Heater inlet and tower exit. Three temperature magnitudes, such as, 50,60 , and $70^{\circ} \mathrm{C}$ at the hot space were used to generate buoyant air flow in the HV-channel,

The velocity magnitude at $\mathrm{RH}$ inlet was too small to measure for all hot space temperatures, hence, excluded, and for remaining two locations is shown in Fig. 3(a). Fig. 3(a) indicates that the air velocity at tower exit is nearly double than that at the heater inlet. Here, the reason is that, the heater inlet area is double than the tower exit area. Further, it indicates that air velocity in the HV-channel increases with increase in temperature of hot space.

The corresponding air mass flow rates calculated at three locations in the HV-channel are shown in Fig. 3(b), and the measured air flow temperatures are indicated in Fig. 3(c). According to Fig. 3(a-c) the air mass flow rate and air flow temperature increase with increase in the temperature of hot space. These Fig. 3(a-c) conclude that hot space temperature acts as air accelerator in the HV-channel which starts from RH inlet and ends to tower exit. The flowing hot air can be utilized for space heating and momentum can be used to generate power.

\subsubsection{Buoyancy-Cum-External Wind Supported Air Flow}

In this case, external wind flow at different speeds was allowed to pass through the $\mathrm{RH}$ using open circuit subsonic wind tunnel and the velocity of air in the HVchannel was kept under observation. In these tests

Mehran University Research Journal of Engineering \& Technology, Volume 36, No. 3, July, 2017 [p-ISSN: 0254-7821, e-ISSN: 2413-7219] 
temperature of hot space was kept same as ambient. Then, in the second step, by changing hot space temperature, combined effect of buoyancy and external wind flow on the air velocity in the HV-channel was investigated.

Fig. 4(a-b), indicate change in air velocity at heater inlet and tower exit, and Fig. 5(a-b), describes air mass flow rate at single entry of RH inlet and tower exit, in the HVchannel verses hot space temperature for different external wind flows.

Here, in Figs. 4-5, four magnitudes of hot space temperatures, such as, $36,50,60$, and $70^{\circ} \mathrm{C}$, have been used, where, the temperature magnitude of $36^{\circ} \mathrm{C}$ represents the ambient temperature.

Figs. 4-5 conclude that, at ambient temperature in the heater space, all the external wind flows cause air mass flow in the HV-channel, which, increases more with increase in the hot space temperature.

The contributions of hot space temperature to generate and increase air mass flow in the HV-channel, without and with $5 \mathrm{~m} / \mathrm{s}$ wind flow from wind tunnel, have been explained through Tables 1-3.

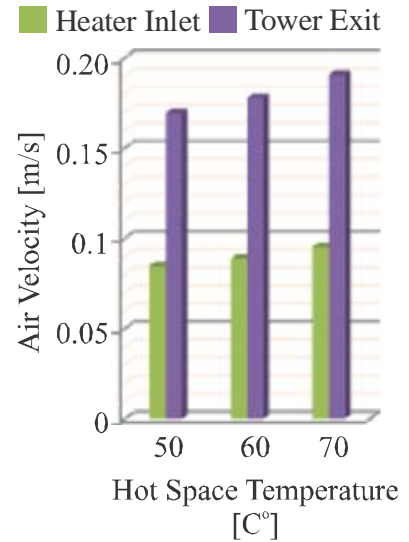

(a)

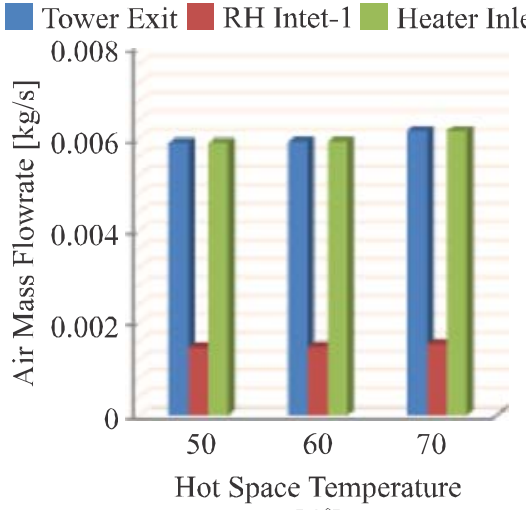

(b)

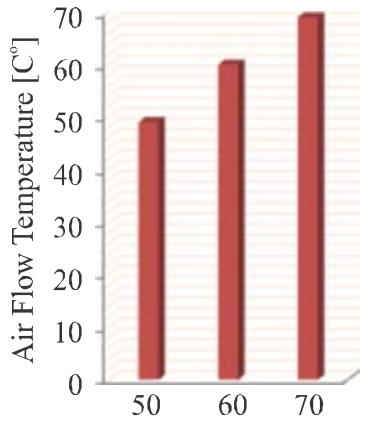

Hot Space Temperature

$\left[\mathrm{C}^{\circ}\right]$

(c)

FIG. 3. AIR FLOW VELOCITY, AIR MASS FLOW RATE AND AIR FLOW TEMPERATURE MEASURED AT DIFFERENT LOCATIONS IN HV-CHANNEL FOR DIFFERENT HSTS

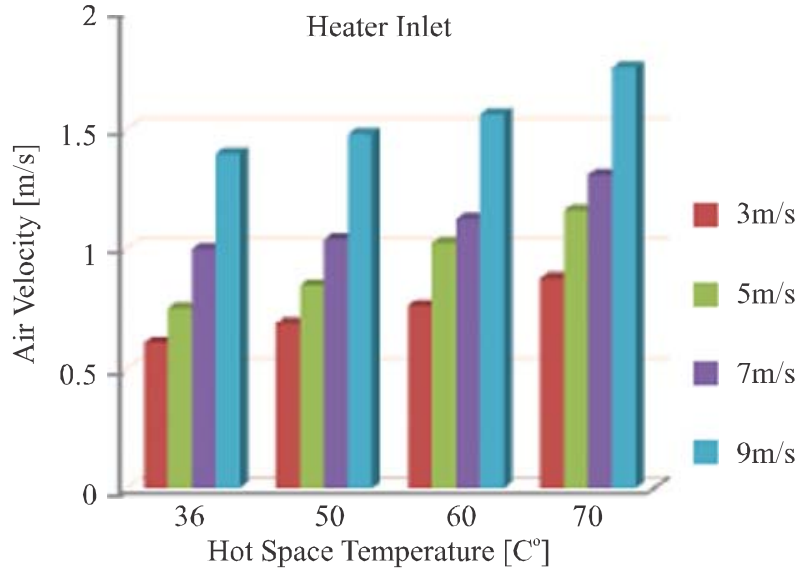

(a) HEATER INLET

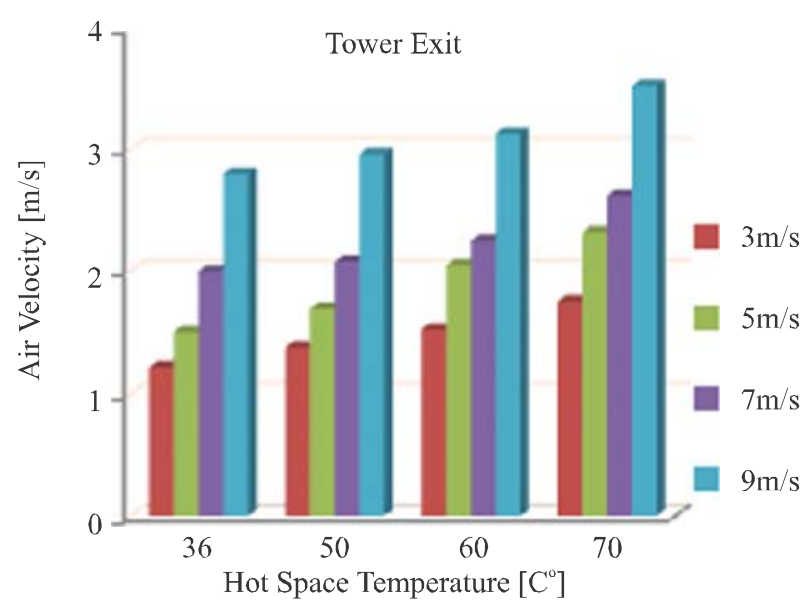

(b) TOWER EXIT

FIG. 4. AIR VELOCITY IN THE HV-CHANNEL VERSES HST COMBINED WITH DIFFERENT EXTERNAL WINDFLOWS 
Table 1 indicates that in the absence of wind flow from wind tunnel, at $36^{\circ} \mathrm{C}$ (ambient temperature), there is no any air mass flow in the HV-channel, whereas, at other hot space temperatures air flow in the HV-channel has been generated which increases with increase in hot space temperature. Nevertheless, at $5 \mathrm{~m} / \mathrm{s}$ wind flow from wind tunnel and at ambient temperature in the hot space, air velocity of $0.75 \mathrm{~m} / \mathrm{s}$ at the heater inlet and $1.51 \mathrm{~m} / \mathrm{s}$ at tower exit, in the HV-channel, have been achieved. Further, with increase in hot space temperature in three steps, such as, 50,60 , and $70^{\circ} \mathrm{C}$, increase in the air velocity at tower exit of the HV-channel was recorded as $12.58,35.76$, and $60.26 \%$, respectively.

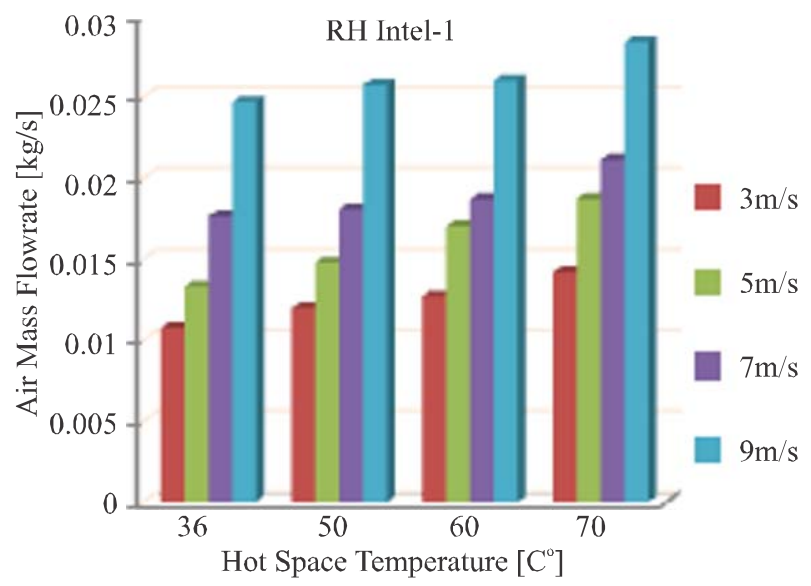

(a) SINGLE ENTRY OF RH
The air mass flow rate for the same test case has been described through Table 2 which shows $0.053 \mathrm{Kg} / \mathrm{s}$ mass flow rate at the tower exit with $5 \mathrm{~m} / \mathrm{s}$ wind speed from wind tunnel at ambient temperature. Further, by setting hot space temperature in three magnitudes, such as, 50, 60, and $70^{\circ} \mathrm{C}$, increase in the air mass flow rate at tower exit of the HV-channel was recorded as 11.32 , 28.3, and $41.5 \%$, respectively.

Air flow temperature in the $\mathrm{HV}$-channel has been investigated which is explained through Table 3. Temperature of air flowing out of the tower exit of the HVchannel depends upon hot space temperature and the air mass flow rate at the tower exit. For same values of hot

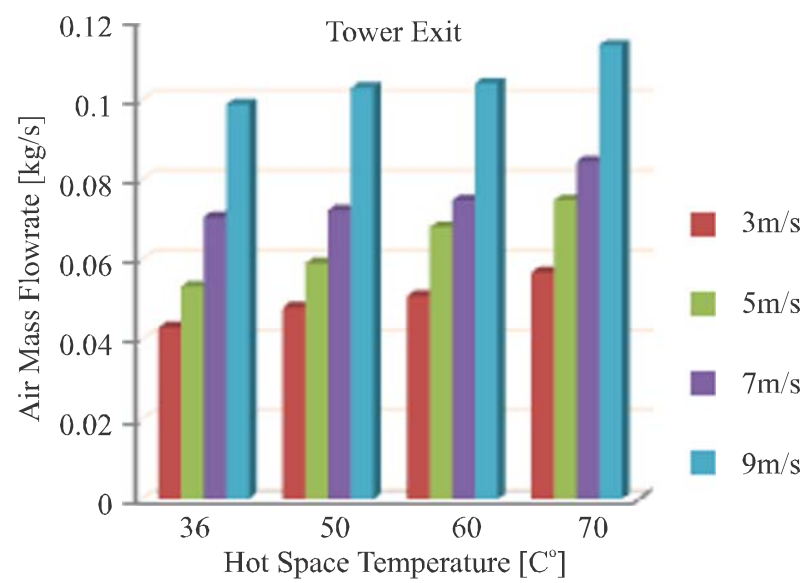

(b) TOWER EXIT

FIG. 5. AIR MASS FLOW RATE IN THE HV-CHANNEL VERSES HST COMBINED WITH DIFFERENT EXTERNAL WIND FLOWS

TABLE 1. AVERAGE AIR VELOCITY IN THE HV-CHANNEL CAUSED BY BUOYANCY ALONE AND BUOYANCY-CUMEXTERNAL WIND FLOW

\begin{tabular}{|c|c|c|c|c|c|c|c|}
\hline \multirow{3}{*}{$\begin{array}{l}\text { Hot Space } \\
\text { Temperature } \\
\quad\left({ }^{\circ} \mathrm{C}\right)\end{array}$} & \multicolumn{6}{|c|}{ Average Air Velocity in the HV-Channel(m/s) } & \multirow{4}{*}{$\begin{array}{l}\text { Velocity Increase at the Tower Exit } \\
\text { Contributed by HST } \\
\text { (\%) }\end{array}$} \\
\hline & \multicolumn{3}{|c|}{ Buoyancy Operated Air Flow } & \multicolumn{3}{|c|}{$\begin{array}{l}\text { Buoyancy-Cum-External } \\
\text { Wind Supported Air Flow } \\
\text { (V=5m/s) }\end{array}$} & \\
\hline & $\begin{array}{l}\text { At RH Inlet } \\
(\mathrm{m} / \mathrm{s})\end{array}$ & $\begin{array}{c}\text { At Heater Inlet } \\
(\mathrm{m} / \mathrm{s})\end{array}$ & $\begin{array}{l}\text { At Tower Exit } \\
(\mathrm{m} / \mathrm{s})\end{array}$ & $\begin{array}{l}\text { At RH Inlet } \\
(\mathrm{m} / \mathrm{s})\end{array}$ & $\begin{array}{c}\text { At Heater Inlet } \\
(\mathrm{m} / \mathrm{s})\end{array}$ & $\begin{array}{l}\text { At Tower Exit } \\
(\mathrm{m} / \mathrm{s})\end{array}$ & \\
\hline 36 & - & & & - & 0.75 & 1.51 & \\
\hline 50 & - & 0.0847 & 0.1694 & - & 0.85 & 1.70 & 12.58 \\
\hline 60 & - & 0.089 & 0.178 & - & 1 & 2.05 & 35.76 \\
\hline 70 & - & 0.0953 & 0.1906 & - & 1.16 & 2.42 & 60.26 \\
\hline
\end{tabular}

Mehran University Research Journal of Engineering \& Technology, Volume 36, No. 3, July, 2017 [p-ISSN: 0254-7821, e-ISSN: 2413-7219] 
space temperature the temperature of air leaving the tower is different for different air mass flow rates and shows inverse relation with the air mass flow rate.

\subsection{Effect of Air Flow in the HV-Channel on the Performance of Vertical Rotor in the WAG-RH}

The previous section concludes that hot space temperature, showing buoyancy principle, acts as air accelerator in HV-channel. Since, the air flow channel passes from the rotor zone, therefore, the flow must exert force on the rotor blades. Nevertheless, the air flow in the channel changes direction from horizontal to vertical without applying significant force on the vertical rotor in the WAG-RH, therefore, the vertical axis rotor shows no performance with this flow, alone, for all hot space temperatures.
Further, the investigations were carried out to observe the effect of air flow in the HV-channel developed due to combined action of buoyancy and external windon the performance of vertical rotor in the WAG-RH.

In this connection the rotor performance in the WAG-RH without and with integration of air heater was tested and compared at different wind speeds from wind tunnel.

The test results are shown in Fig. 6 which reflects no or minor effect of air heater integration on the performance of vertical axis rotor in the WAG-RH.

Here, in Figs. 6-7, VRW stands for Vertical axis Rotor in WAG-RH, and AH stands for Air Heater are graphically presented.

TABLE 2. AVERAGE AIR MASS FLOWRATE IN THEHV-CHANNEL CAUSED BY BUOYANCY ALONE AND BUOYANCYCUM-EXTERNAL WIND FLOW

\begin{tabular}{|c|c|c|c|c|c|c|c|}
\hline \multirow{3}{*}{$\begin{array}{c}\text { Hot Space } \\
\text { Temperature } \\
\left({ }^{\circ} \mathrm{C}\right)\end{array}$} & \multicolumn{6}{|c|}{ Average Air Mass Flow Rate in the HV-Channel(Kg/s) } & \multirow{4}{*}{$\begin{array}{c}\text { Mass Flow Rate Increase } \\
\text { at the Tower Exit } \\
\text { Contributed by HST } \\
(\%)\end{array}$} \\
\hline & \multicolumn{3}{|c|}{ Buoyancy Operated Air Flow } & \multicolumn{3}{|c|}{$\begin{array}{l}\text { Buoyancy-Cum-External } \\
\text { Wind Supported Air Flow } \\
(\mathrm{V}=5 \mathrm{~m} / \mathrm{s})\end{array}$} & \\
\hline & $\begin{array}{c}\text { At RH Inlet } \\
(\mathrm{m} / \mathrm{s})\end{array}$ & $\begin{array}{l}\text { At Heater Inlet } \\
(\mathrm{m} / \mathrm{s})\end{array}$ & $\begin{array}{l}\text { At Tower Exit } \\
\qquad(\mathrm{m} / \mathrm{s})\end{array}$ & $\begin{array}{l}\text { At RH Inlet } \\
(\mathrm{m} / \mathrm{s})\end{array}$ & $\begin{array}{l}\text { At Heater Inlet } \\
(\mathrm{m} / \mathrm{s})\end{array}$ & $\begin{array}{l}\text { At Tower Exit } \\
\qquad(\mathrm{m} / \mathrm{s})\end{array}$ & \\
\hline 36 & --- & --- & --- & 0.013 & 0.053 & 0.053 & \\
\hline 50 & 0.0012 & 0.006 & 0.006 & 0.014 & 0.059 & 0.059 & 11.32 \\
\hline 60 & 0.0014 & 0.007 & 0.007 & 0.017 & 0.068 & 0.068 & 28.3 \\
\hline 70 & 0.0015 & 0.006 & 0.006 & 0.018 & 0.075 & 0.075 & 41.5 \\
\hline
\end{tabular}

TABLE 3. AVERAGE AIR FLOW TEMPERATURE IN THE HV-CHANNEL CAUSED BY BUOYANCY ALONE AND BUOYANCY-CUM-EXTERNAL WIND FLOW

\begin{tabular}{|c|c|c|c|c|c|c|}
\hline \multirow{2}{*}{$\begin{array}{c}\text { Hot Space } \\
\text { Temperature } \\
\left({ }^{\circ} \mathrm{C}\right)\end{array}$} & \multicolumn{4}{|c|}{ Average Air Flow Temperature in the HV-Channel(oC) } \\
\cline { 2 - 8 } & $\begin{array}{c}|c| \\
\text { At RH Inlet } \\
(\mathrm{m} / \mathrm{s})\end{array}$ & $\begin{array}{c}\text { At Heater Inlet } \\
(\mathrm{m} / \mathrm{s})\end{array}$ & $\begin{array}{c}\text { At Tower Exit } \\
(\mathrm{m} / \mathrm{s})\end{array}$ & $\begin{array}{c}\text { At RH Inlet } \\
(\mathrm{m} / \mathrm{s})\end{array}$ & $\begin{array}{c}\text { At Heater Inlet } \\
(\mathrm{m} / \mathrm{s})\end{array}$ & $\begin{array}{c}\text { At Tower Exit } \\
(\mathrm{m} / \mathrm{s})\end{array}$ \\
\hline 36 & - & - & - & 36 & 36 & 36 \\
\hline 50 & 37 & 39 & 49 & 36 & 36 & 45.6 \\
\hline 60 & 37 & 41 & 60 & 36 & 36 & 36 \\
\hline 70 & 38 & 41 & 69 & 36 & 36 & 36 \\
\hline
\end{tabular}

Mehran University Research Journal of Engineering \& Technology, Volume 36, No. 3, July, 2017 [p-ISSN: 0254-7821, e-ISSN: 2413-7219] 


\subsection{Effect of Air Flow in the HV-Channel on the Performance of VRW using Vertical Horizontal Co-Axial Blades Combination Technique}

In the previous section it was indicated that the air flow channel changes direction from horizontal to vertical without applying significant force on the vertical rotor in the WAG-RH. The vertical flow starts in concentrated form from the heater inlet where the shaft of vertical rotor ends. Fixing four bladed horizontal axis setup with the end of this vertical shaft, vertical air flow at the heater inlet was trapped. The trapped flow exerts force on the blades and the blades, take turning effect. Though, the force carried by the trapped flow being small cannot rotate the rotor setup but tends the rotor to rotate. This tendency of the trapped flow reduces the rotor inertia and improves the starting characteristics, as well as, performance of rotor (when the vertical rotor performs using wind stream from wind tunnel). The comparative results of later VHCBC-technique and other configurations discussed in previous section in terms of their performance contributed at different wind speeds from wind tunnel are shown in Fig. 7.

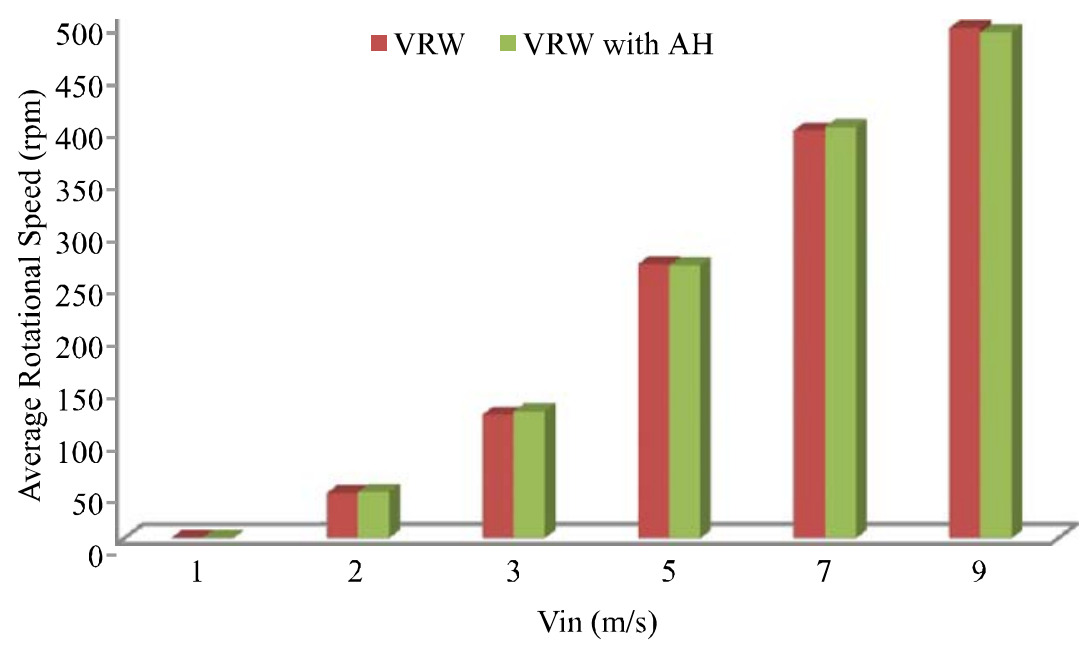

FIG. 6. AVERAGE ROTATIONAL SPEED ACHIEVED BY TWO ROTOR CONFIGURATIONS, VRW AND VRW WITH AH, FOR DIFFERENT WIND VELOCITIES AND AT HST $=70^{\circ} \mathrm{C}$

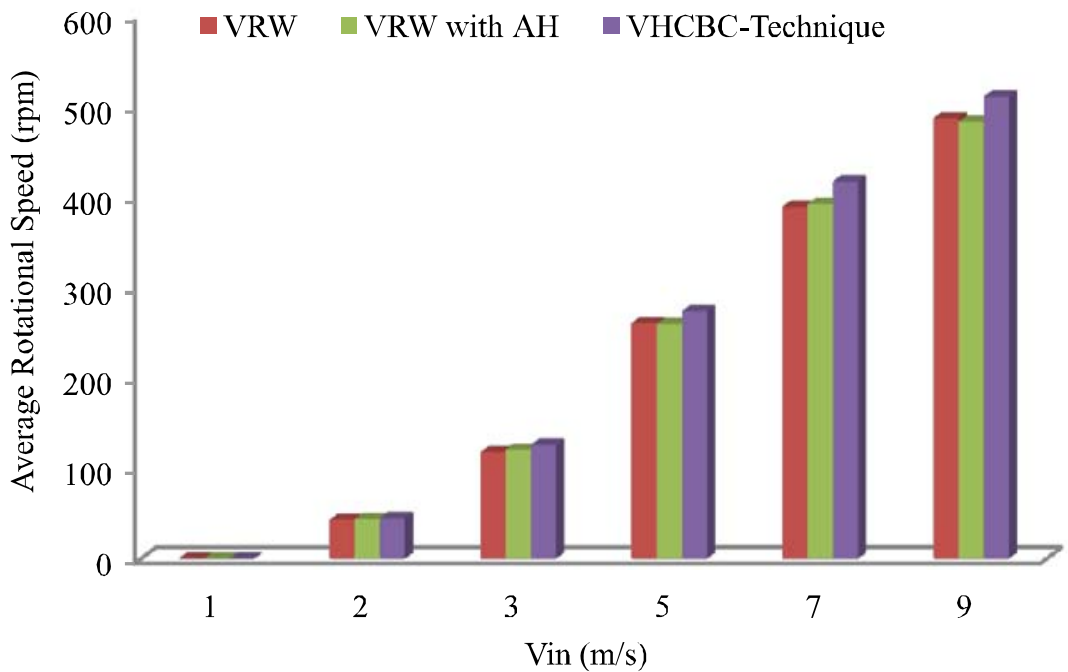

FIG. 7. THE COMPARATIVE RESULTS BY VRW, VRW WITH AH AND VHCBC-TECHNIQUE IN TERMSOF AVERAGE ROTATIONAL SPEED OF ROTOR CONTRIBUTED AT DIFFERENT WIND SPEEDS FROM WIND TUNNEL AND AT HST $=70^{\circ} \mathrm{C}$

Mehran University Research Journal of Engineering \& Technology, Volume 36, No. 3, July, 2017 [p-ISSN: 0254-7821, e-ISSN: 2413-7219] 
Fig. 7 gives clear indication of benefit, in terms of improvements in rotor performance, contributed by air heater integration with WAG-RH when using VHCBCtechnique

The results of these investigations are, further, explained through Fig. 8 which indicates the contribution of VHCBCtechnique in terms of percent increase in the performance of VRW with AH.

The Fig. 8 reflects increase in the performance of vertical axis rotor in WAG-RH contributed by air heater integration with WAG-RH accompanied by VHCBC-technique at all wind speeds.

Further, to investigate performance coefficient for the rotor when working inside solar integrated rotor house, average static torque available on the rotor shaft has been measured at $70^{\circ} \mathrm{C} \mathrm{HST}$ for different external wind speeds as shown in Fig. 9.

Fig. 9 also compares the magnitude of average static torque for the rotor performing in the rotor house (WAG$\mathrm{RH})$ without and with using VHCBC-technique. The Fig. 9 shows better performance of the rotor in the

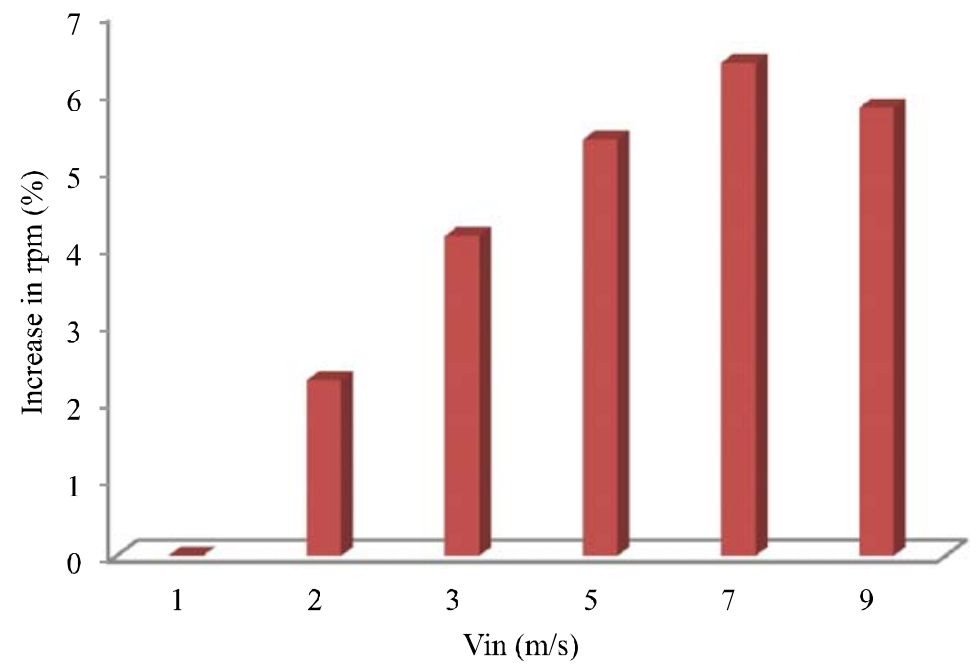

FIG. 8. PERCENT INCREASE IN ROTATIONAL SPEED OF VERTICAL ROTOR IN WAG-RH CONTRIBUTED BY BUOYANCY-CUMEXTERNAL WIND FLOW ACCOMPANIED WITH VHCBC-TECHNIQUE AT HST $=70^{\circ} \mathrm{C}$

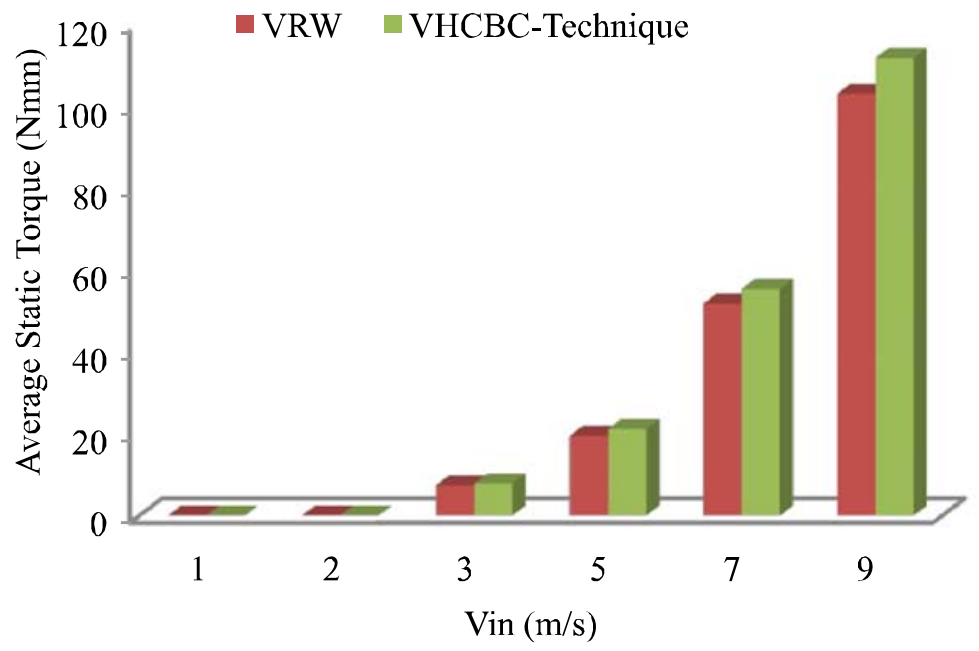

FIG. 9. AVERAGE STATIC TORQUE MEASURED ON THE SHAFT OF ROTOR CONTRIBUTED BY THE WAG-RH(VRW) AND THE WAG-RH USING VHCBC-TECHNIQUE FOR DIFFERENT BUOYANCY-CUM-EXTERNAL WIND FLOWS AT HST $=70^{\circ} \mathrm{C}$

Mehran University Research Journal of Engineering \& Technology, Volume 36, No. 3, July, 2017 [p-ISSN: 0254-7821, e-ISSN: 2413-7219] 
solar integrated rotor house when it uses VHCBCtechnique.

Performance coefficient of the rotor for three different cases, such as bare rotor, rotor in the WAG-RH, and rotor in the solar integrated WAG-RH using VHCBC-technique, has been compared in Fig. 10(a-b).

The percent rise in the Cp of the rotor contributed by the two techniques has been indicated in Fig. 10(b).Excellent rise in the $\mathrm{Cp}$ of the rotor, particularly at low wind speeds, has been contributed by the introduced techniques.

The Fig. 10 shows that both the techniques contribute well for improving performance coefficient (Cp) of vertical axis rotor at different external wind speeds

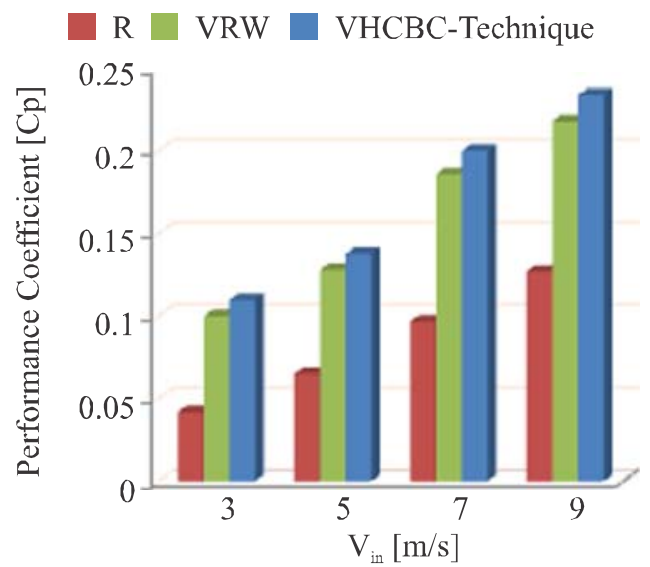

FIG. 10(a). PERFORMANCE COEFFICIENT

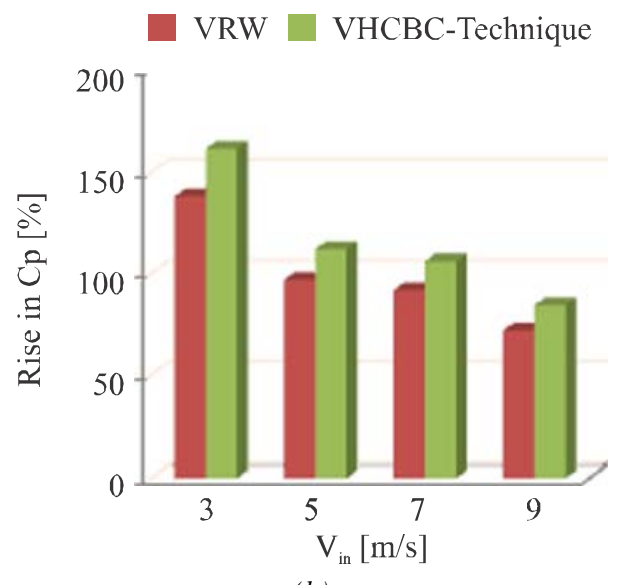

(b)

FIG. 10(b). PERCENT RISE IN CP,OF VARIOUS CONFIGURATIONS OF VERTICAL ROTOR FOR DIFFERENT BUOYANCY-CUM-EXTERNAL WIND FLOWS AT HST $=70^{\circ} \mathrm{C}$

\section{CONCLUSIONS}

Solar air heater as an integral part of WAG-RH has been investigated. The objective was to utilize the flat roof surface area of WAG-RH for solar thermal energy collection and to estimate the effects of buoyancy powered airflow on the performance of rotor in the WAG-RH. The study concludes that:

(i) The hot space temperature generates buoyant airflow in the HV-channel which starts from rotor house inlet and ends at tower exit.

(ii) The power of buoyant air flow, developed in the HV-channel by the solar integrated rotor house, showed no effect on the performance of vertical axis rotor in the rotor house.

(iii) The solar integrated rotor house, implementing VHCBC-Technique, utilized the power of air flow developed in the HV-channel and improved the performance coefficient (Cp) of Savonius three bladed rotor from $0.042-0.11(162 \%$ rise) for external wind flow speed of $3 \mathrm{~m} / \mathrm{s}$ at HST= $70^{\circ} \mathrm{C}$.

(iv) Hot air released from air heater can be utilized for space heating or drying purpose.

\section{ACKNOWLEDGEMENT}

The authors acknowledge and appreciate the technical help provided by Department of Mechanical Engineering, Quaid-e-Awam University of Engineering, Science \& Technology, Nawabshah, Pakistan, for conducting this research.

\section{REFERENCES}

[1] Gullison, R.E., Frumhoff, P.C., Canadell, J.G., and Field, C.B.,”Tropical ForestsandClimate Policy”, Science, Volume 316, pp. 985-986, 2007.

Mehran University Research Journal of Engineering \& Technology, Volume 36, No. 3, July, 2017 [p-ISSN: 0254-7821, e-ISSN: 2413-7219] 
[2] Kerr, R.A., "Global Warming is Changing the World”, Science, Volume 316, pp. 188-190, 2007.

[3] Stern, N., "The Economics of Climate Change”, The Stern Review, Cambridge University Press, UK, 2007.

Mathiesen, B.V., Lund, H., and Karlsson K., “100\% Renewable Energy Systems, Climate Mitigation and Economic Growth”, Applied Energy, Volume 88, No. 2, pp. 488-501, 2011.

Jacobson, M.Z., and Delucchi, M.A.,” Providing all Global Energy with Wind, Water, and Solar Power, PartI: Technologies, Energy Resources, Quantities and Areas of Infrastructure, and Materials”, Energy Policy, Volume 39, No. 3, pp. 1154-1169, 2011.

IEA, “Technology Roadmap Wind Energy”, International Energy Agency, OECD Publication Service, Paris, 2009.

Santos-Alamillos,F.J., Pozo-Vazquez, D., Ruiz-Arias, J.A., Von Bremen, L., and Tovar-Pescador,J.,"Combining Wind Farms with Concentrating Solar Plants to Provide Stable Renewable Power”, Renewable Energy, Volume 76, pp. 539-550, 2015.

Stankovic, S., Campbell, N., and Harries, A., "Urban Wind Energy”, Earthscan, London, 2009.

Ledo,L.,Kosasih,P.B., andCooper,P.,”Roof Mounting Site Analysis for Micro-Wind Turbines”, Renewable Energy, Volume 36, pp. 1379e91, 2011.

[10] Igra, O.,"Cost-Effectiveness of the Vortex-Augmented Wind Turbine”, Energy, Volume 4, pp. 119-130, 1979.

[11] Abe, K., Nishida, M., Sakurai, A., Ohya, Y., and Kihara, H., "Experimental and Numerical Investigations of Flow Fields Behind a Small Wind Turbine with a Flanged Diffuser”,Journal of Wind Energy Industrial Aerodynam, Volume 93, pp. 951-970, 2005.
[12] Ohya, Y., Karasudani, T., Sakurai, A., Abe, K., and Inoue, M., "Development of a Shrouded Wind Turbine with a Flanged Diffuser”, Journal of Wind Energy Industrial Aerodynam, Volume96, pp. 524-39, 2008.

Ayhana, D., Saglam,and Safak, “A Technical Review of Building-Mounted Wind Power Systems anda Sample Simulation Model”, Renew Sustain Energy Review, Volume 16, pp. 1040-9, 2012.

[14] Booker, J.D., Mellor, P.H., Wrobel, R., and Drury, D., "A Compact, High Efficiency Contra Rotating Generator Suitable for Wind Turbines in the Urban Environment”,Renew Energy, Volume 35, pp. 2027-33, 2010.

[15] Chen, T.Y., Liao, Y.T., and Cheng, C.C., "Development of Small Wind Turbines for Moving Vehicles: Effects of Flanged Diffusers on Rotor Performance”, Experimental Thermal Fluid Science, Volume 42, pp. 136-42, 2012.

[16] Grassmann, H., Bet, F., Cabras, G., Ceschia, M., Cobai, D., and DelPapa, C., “A Partially Static Turbine-First Experimental Results”, Renew Energy, Volume 28, pp. 1779-1785, 2003.

[17] Rhee, D.H., and Cho, H.H.,"Effect of Vane/Blade Relative Position on Heat Transfer Characteristics in a Stationary Turbine Blade: Part-1. Tip and Shroud”, International Journal of Thermal Science, Volume 47, pp. 1528-43, 2008.

[18] Igra, O.,’Research and Development for Shrouded Wind Turbines”, Energy Conversation Management, Volume 21, pp. 13-48, 1981.

[19] Celik, A.N., Muneer, T., and Clarke, P., “An Investigation into Micro Wind Energy Systems for their Utilization in Urban Areas and their Life Cycle Assessment”, Proceedings of Institute of Mechanical Engineering PartA, Journal of PowerEnergy, Volume 221, pp. 1107-1117, 2007.

[20] Chen, H.C., "Optimum Capacity Determination of Stand-Alone Hybrid Generation System Considering Cost and Reliability”, Applied Energy, Volume 103, pp. 155-164, 2013. 
[21] Qunwu, H., Yeqiang, S., Yiping, W., Linping, L., and Yong, C., "Multi-Turbine Wind-Solar Hybrid System", Renewable Energy, Volume 76, pp. 401-407, 2015.

[22] Chitsomboon, T.,”A Validated Analytical Model for Flow in Solar Chimney”, International Journal of Renewable Energy Engineering,Volume 3,pp. 339-346,2000.

[23] Chitsomboon, T., and Tongbai, P., “A Mathematical Model of Solar Chimney for Electrical EnergyProduction”, Proceedings of 12th National Mechanical Engineering Conference, Chulalongkorn University, pp. 14-20, Thailand, 1998.
[24] Chitsomboon, T., and Tongbai, P., "The Effect of Chimney-Top Convergence on Efficiency of a Solar Chimney”, Proceedings of 13th National Mechanical Engineering Conference, pp. 263-268,Pataya, Thailand, 1999.

[25] Manganhar, A.L., Samo, S.R., Luhur, M.R., and Rajpar, A.H., "Vertical Ducting and Vertical-Horizontal Coaxial Blade Combination Effects on the Performanceof Vertical Axis Wind Turbine(VAWT)”, Quaid-e-Awam University Research Journal of Engineering, Science \& Technology, Volume 13, No.1, Nawabshah, Pakistan, January-June 2014. 